\title{
The ideas of people referred to neurologists about managing their headaches: A qualitative study
}

\author{
F Nadeem*', A Noble, L Ridsdale, M Morgan \\ From The European Headache and Migraine Trust International Congress \\ London, UK. 20-23 September 2012
}

\section{Introduction}

Headache is the commonest reason for General Practitioner (GP) referrals to neurologists, accounting for $25 \%$ of all referrals. Those that are referred, however, constitute only $2 \%$ of patients who consult GPs with headache. Previous research has suggested that referred patients are more fearful and anxious about their symptoms than those managed without referral. GPs described pressure to refer, often for a brain scan. We now report patients' perspectives.

\section{Aims/objectives}

The aim of this study was to explore the view of people consulting GPs with headache who were referred to neurologists.

\section{Methods}

A qualitative study using semi-structured interviews with nineteen adults aged 23-63, referred by their GPs to neurologists for primary headaches. Audio-recorded interviews were transcribed and analysed thematically.

\section{Results}

Participants described recurring concerns about secondary organic causes for headache, like a brain tumour. They described their headaches as stressful and a vicious cycle, with further headaches occurring. Some reported catastrophic fears, leading them to attend A\&E. Many believed they needed a brain scan, and over half had had a scan, all of which were normal. Many reported dissatisfaction with care and use of alternative therapies.

\section{Conclusion}

People referred to neurologists for headache described fear and distress, particularly about the possibility of a brain

Kings College London, UK

(c) 2013 Nadeem et al; licensee Springer. This is an Open Access article distributed under the terms of the Creative Commons Attribution License (http://creativecommons.org/licenses/by/2.0), which permits unrestricted use, distribution, and reproduction in any medium, provided the original work is properly cited. tumour. GPs now have open access to scanning. This may relieve physical concerns. Interventions to address healthrelated anxiety may help some consulters for headache too.

Published: 21 February 2013

\section{References}

1. Morgan $M$, Jenkins $L$, Ridsdale $L$ : Patient pressure for referral for headache: a qualitative study of GPs' referral behaviour. $\mathrm{Br} J \mathrm{Gen}$ Pract 2007, 57:29-35

2. Ridsdale $L$, Clark L, Dowson A, Godlstein L, Jenkins $L$, McCrone $P$, Morgan $M$, Seed $P$ : How do patients referred to neurologists for headache differ from those managed in primary care? British Journal of General Practice 2007, 57:388-395.

doi:10.1186/1129-2377-14-S1-P203

Cite this article as: Nadeem et al:: The ideas of people referred to neurologists about managing their headaches: A qualitative study. The Journal of Headache and Pain 2013 14(Suppl 1):P203.

Submit your manuscript to a SpringerOpen ${ }^{\ominus}$ journal and benefit from:

- Convenient online submission

- Rigorous peer review

- Immediate publication on acceptance

- Open access: articles freely available online

- High visibility within the field

- Retaining the copyright to your article

Submit your next manuscript at springeropen.com 